\title{
Three species of Calydiscoides (Monogenea: Diplectanidae) from five Lethrinus spp. (Lethrinidae: Perciformes) off New Caledonia, with a description of Calydiscoides terpsichore sp. $\mathbf{n}$.
}

\author{
Guilhem Rascalou and Jean-Lou Justine
}

\begin{abstract}
Équipe Biogéographie Marine Tropicale, Unité Systématique, Adaptation, Évolution (CNRS, UPMC, MNHN, IRD), Institut de Recherche pour le Développement, BP A5, 98848 Nouméa Cedex, Nouvelle-Calédonie
\end{abstract}
Key words: Monogenea, Diplectanidae, Calydiscoides difficilis, Calydiscoides duplicostatus, Calydiscoides terpsichore, Lethrinus, host specificity, South Pacific

\begin{abstract}
Numerous specimens of Calydiscoides spp. from Lethrinus nebulosus and L. harak, and fewer specimens from $L$. lentjan, L. ravus and L. obsoletus, collected off New Caledonia, South Pacific, were examined. Three species of Calydiscoides were recognized. Calydiscoides difficilis (Yamaguti, 1953) Young, 1969 was generally the most abundant species on the five hosts. Specimens of $C$. difficilis were measured and compared to the type specimens (from Indonesia) and museum vouchers (from Australia and the Arabian Gulf). The morphology of the massive male copulatory organ and of haptoral sclerotized parts was similar, but specimens from the same host and from different hosts showed wide morphometric variations; it is concluded that $C$. difficilis has a high degree of variability, although the possibility of a species complex remains. Calydiscoides duplicostatus (Yamaguti, 1953) Young, 1969 was found on L. nebulosus, L. harak and L. lentjan; specimens were homogeneous in the three hosts and similar to the type specimens. Calydiscoides terpsichore sp. n. is described from L. nebulosus (type host) and $L$. harak and was uncommon in both fish. The new species, a member of the 'australis group', is characterized by its Y-shaped male copulatory organ, with the left branch bearing a trifurcated secondary branch. Lethrinus nebulosus and L. harak shared the 3 species of Calydiscoides studied here, a fact probably related with their close phylogenetic relationships. Among the 15 species of Lethrinus present in New Caledonia, 11 were examined and 9 species harboured 1-3 species of Calydiscoides each. Only 7 species of Calydiscoides were found, due to their stenoxenous specificity. Each species of Calydiscoides has 1 to 5 hosts.
\end{abstract}

The fish fauna of the lagoon of New Caledonia is characterized by an exceptional abundance of lethrinids, or emperors (Laboute and Grandperrin 2000). The family is represented in New Caledonia by 25 species, including 15 species of Lethrinus (see Fricke and Kulbicki 2006; Table 4). Most of these Lethrinus spp. harbour species of Calydiscoides. Justine (2007a) reported Calydiscoides spp. from L. miniatus, L. atkinsoni, L. rubrioperculatus and L. xanthochilus. In this paper, we continue a survey of the monogenean fauna of lethrinids with L. nebulosus, locally called 'bec de cane', probably the most important species for local fisheries, and $L$. harak, which is closely related to the former species (Lo Galbo et al. 2002). Both species have a wide distribution in the Indo-Pacific region. Information on a smaller number of specimens was also obtained for three additional species, L. lentjan, L. ravus and L. obsoletus, and negative results are reported for $L$. genivittatus and $L$. variegatus. Finally, data about the diplectanid fauna are reported for 11 of the 15 species of Lethrinus present in New Caledonia.

Members of Calydiscoides Young, 1969 are characterized by two lamellodiscs with concentric lamellae which telescope into each other, and are parasites exclusively in fishes of the family Lethrinidae and Nemipteridae in the Indo-Pacific region. The genus was re- vised by Oliver (1987), Thoney (1989), and Lim (2003). Justine (2007a) updated the lists of species and hosts, described C. euzeti Justine, 2007 from L. rubrioperculatus and L. xanthochilus and proposed to distinguish two groups within Calydiscoides on the basis of the male copulatory organ, the 'difficilis group' and the 'australis group'.

\section{MATERIALS AND METHODS}

Specimens of Lethrinus spp. were caught with hand lines on board R/V "Coris" or spear-fished (see list of stations). Live fish were kept in a container with seawater and immediately brought back to the laboratory. All fish were measured, weighed, and photographed. A unique number (JNC) was assigned to each fish. The parasitological material was then assigned a corresponding JNC linked to the respective fish host. Measurements of hosts (FL, fork length, in $\mathrm{mm}$; W, weight, in g) are indicated for possible future comparison of parasite prevalence and host age in other localities and because the monogenean fauna has been showed to change according to fish size (Hinsinger and Justine 2006).

List of stations. Stations are within the lagoon off Nouméa, New Caledonia, with a depth of 2-20 m. Stn I1, 26.iii.2003, Grande Rade, $22^{\circ} 14^{\prime}$ 'S, $166^{\circ} 24^{\prime} E$; Stn I2, 20.xi.2003, Baie de Maa, $22^{\circ} 12^{\prime} \mathrm{S}, 166^{\circ} 20^{\prime} \mathrm{E}$; Stn I3, 21.ii.2006, Ilôt Maître, $22^{\circ} 20^{\prime}$ S, $166^{\circ} 24^{\prime}$; Stn I4, 7.iii.2006,

Address for correspondence: J.-L. Justine, Équipe Biogéographie Marine Tropicale, Unité Systématique, Adaptation, Évolution (CNRS, UPMC, MNHN, IRD), Institut de Recherche pour le Développement, BP A5, 98848 Nouméa Cedex, Nouvelle-Calédonie. Phone: ++ 687 260 810 ; Fax: ++ 687264 326; E-mail: justine@ird.nc 
Ilôt La Regnière, $22^{\circ} 19^{\prime}$ S, $166^{\circ} 19^{\prime}$; Stn I5, 14.iii.2006, Ilôt Canard, $22^{\circ} 18^{\prime}$ S, $166^{\circ} 26^{\prime} \mathrm{E}$; Stn I6, 28.iii.2006, Ilôt Canard; Stn I7, 4.iv.2006, Ilôt Maître; Stn I8, 16.v.2006, Ilôt Signal, $22^{\circ} 17^{\prime}$ S, $166^{\circ} 17^{\prime} \mathrm{E}$; Stn I9, 17.x.2006, Baie des Citrons, $22^{\circ} 18^{\prime} \mathrm{S}, 166^{\circ} 26^{\prime} \mathrm{E}$.

Fish used for collection of Calydiscoides spp. Lethrinus harak: 7 individuals, JNC1750, FL 232, W 239, Stn I3; JNC1751, FL 228, W 230, Stn I3; JNC1752, FL 238, W 247, Stn I3; JNC1770, FL 260, W 337, Stn I5; JNC1771, FL 213, W 189, Stn I5; JNC1772, FL 256, W 321, Stn I5; JNC1784, FL 148, W 289, Stn I6. L. nebulosus: 2 individuals, JNC967, FL 280, W 402, Stn I2; JNC1785, FL 470, W 1800, Stn I7. L. lentjan: 2 individuals, JNC334, FL 225, W 205, Stn H1; JNC335, FL 185, W 115, Stn H1. L. ravus: 3 individuals, JNC1761, FL 190, W 133, Stn I4; JNC1762, FL 195, W 142, Stn I4; JNC1763, FL 201, W 157, Stn I4. L. obsoletus: 1 individual, JNC1829, FL 241, W 275, Stn I8. L. variegatus: 1 individual, JNC2077, FL 198, W 119, Stn 19 (no diplectanid, but presence of ancyrocephalids). L. genivittatus: numerous $(>30)$ specimens of this very common fish, from various stations around Nouméa, not enumerated, 2003-2006, no monogenean found.

Monogeneans were collected, prepared and drawn as indicated in Justine (2005, 2007a). Measurements of male copulatory organs (MCOs), taken as longest length of organ, and measurement of haptoral hard-parts, were as in Justine 2007a, fig. 1; after a preliminary test to check absence of lateral asymmetry, measurements of the right-hand haptoral hardparts and left-hand equivalents were pooled. Measurements of monogeneans in ammonium picrate preparations and in specimens prepared in ethanol are significantly different (Justine 2005); in this paper, only measurements of 'carmine' specimens are given for soft parts; measurements of 'carmine' and 'picrate' specimens are both given for sclerotized parts. 'Unflattened carmine' specimens were not used for the description of the new species. All measurements are given in micrometres as the holotype and mean followed by the range and number of measurements in parentheses. Names of fish are according to Froese and Pauly (2006).

Abbreviations. MNHN, Muséum national d'Histoire Naturelle, Paris; BMNH, Natural History Museum, London; USNPC, United States National Parasite Collection, Beltsville; MPM, Meguro Parasitological Museum, Tokyo; HCIP, Helminthological Collection, Institute of Parasitology, Biology Centre, Academy of Sciences of the Czech Republic, České Budějovice.

\section{DESCRIPTIONS}

\section{Calydiscoides difficilis (Yamaguti, 1953) Young, 1969 \\ Syn. Lamellodiscus difficilis Yamaguti, 1953.}

Description of the material from New Caledonia (Figs. 1, 2). Organisation of internal soft organs similar to Calydiscoides terpsichore (see later). MCO massive, made up of two parts, anterior and posterior, both heavily sclerotized (measurements in Table 2). Sclerotized vagina a round sac sometimes filled with material. Haptoral parts: elongate ventral bar, slightly bow-shaped and curved posteriorly, with indentation on central part of posterior edge and extremities curved posteriorly; dorsal (lateral) bars elongate, each with an external (lateral) hook, directed posteriorly, and medial bifurcated extremity; ventral hamuli elongate, with distinct inner and outer roots; dorsal hamuli elongate, with indistinct inner root (guard). Large lamellodiscs, with 1011 lamellae including 3 closed rings.

Measurements of sclerotized parts were taken on more than 100 specimens mainly from Lethrinus nebulosus and L. harak, and also from L. lentjan, L. ravus and L. obsoletus, and are presented in Table 2. Histograms of measurements generally used for systematics of diplectanids are shown in Fig. 2 for specimens from two hosts, L. nebulosus and L. harak. Measurements of specimens from each host show wide intra-host variation, and we could not detect morphological differences between the specimens, even in comparing the specimens with smallest and largest measurements (Fig. 1). Specimens from $L$. nebulosus generally have longer measurements for the MCO and all haptoral parts than specimens from L. harak. The means are often significantly different, but histograms show that measurements from the two hosts overlap for all structures (Fig. 2). Measurements of the holotype generally fall in the zone of overlap of the two main host species, L. nebulosus vs. L. harak (Fig. 2).

T y p e hos t: Lethrinus sp. (Lethrinidae). Species not indicated in the original description (Yamaguti 1953), but it was the same individual fish as for C. duplicostatus (see Justine 2007a).

$\mathrm{O}$ t h e r h o s t s : L. laticaudis (designated as L. fletus, see Young 1969, 1970); L. reticulatus (see Young 1969, 1970); L. nebulosus (see Oliver 1984, and this work); L. miniatus (see Oliver 1984, Rohde et al. 1994, 1995); L. harak, L. lentjan, L. ravus, L. obsoletus (this work).

$\mathrm{S}$ i t e : Between secondary gill lamellae.

T y p e 1 o c a 1 i t y : Macassar, Celebes (now Ujungpandang, Sulawesi), Indonesia.

O t h e r 1 o c a 1 i t i e s : Australia (Young 1969, 1970, Oliver 1984); Arabian Gulf (this work); New Caledonia (this work).

Material from New Caledonia: 639 specimens examined; 246 from L. nebulosus; 329 from L. harak; 11 from L. lentjan; 4 from $L$. ravus; 49 from L. obsoletus (see Table 1).

Other material ex a m in ed: MPM 22559, 1 slide SY 6730, holotype and other specimens in type slide (redescribed in Justine 2007a); USNPC 63155, 2 slides 1004-25 and 1004-26, from L. laticaudis (designated as L. fletus) from Tangalooma, Australia, deposited by Young and probably corresponding to the material mentioned in Young (1969, 1970); MNHN 186TC Tj126, from L. nebulosus from Heron Island, Australia (described in Oliver 1984); BMNH 1994.8.10.96-97 and 1994.8.1.98-100, 2 slides from $L$. harak from the Arabian Gulf, deposited by I. Al Mathal; these slides contain 5 specimens of $C$. difficilis and an undescribed ancyrocephalid, and were apparently never mentioned in a publication. 


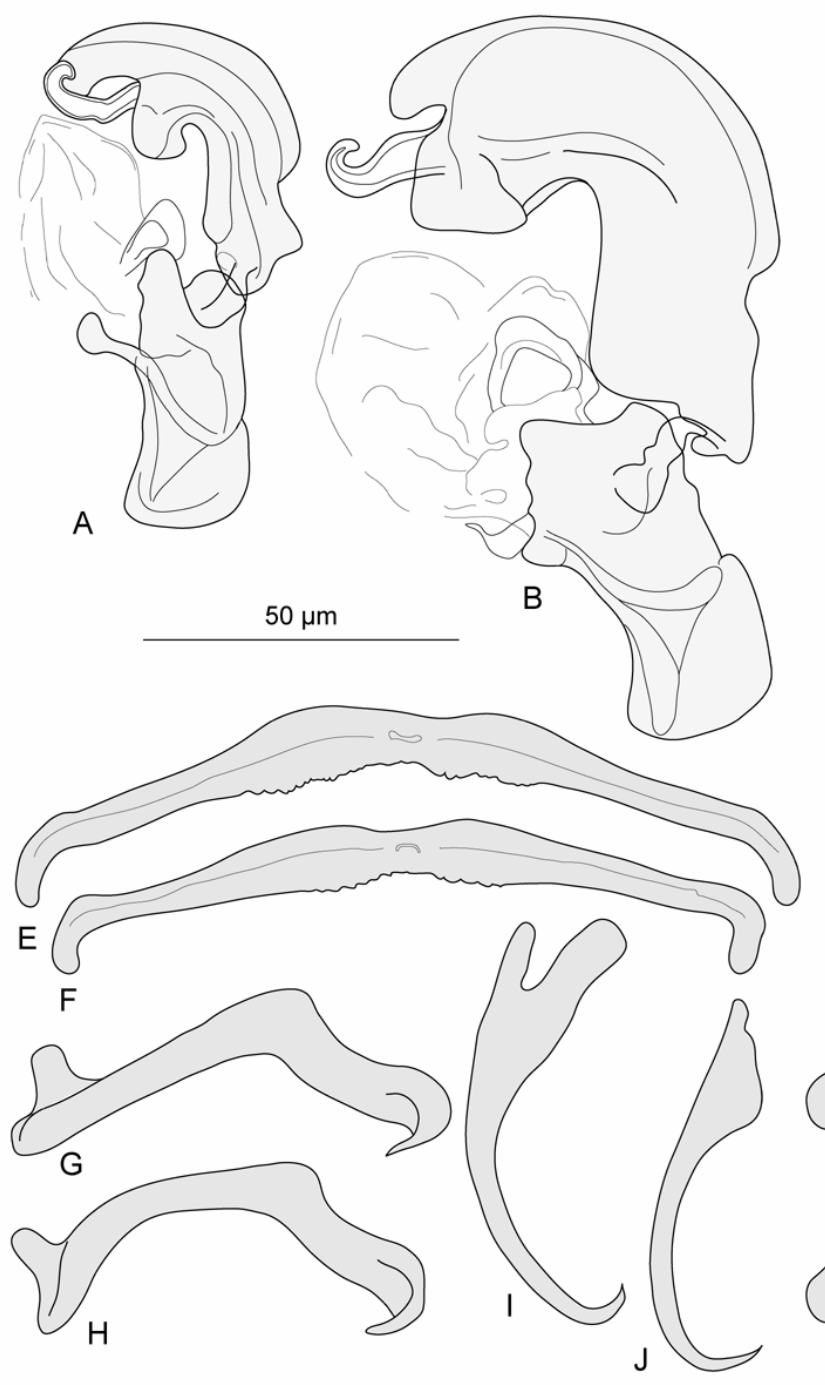

Lethrinus nebulosus
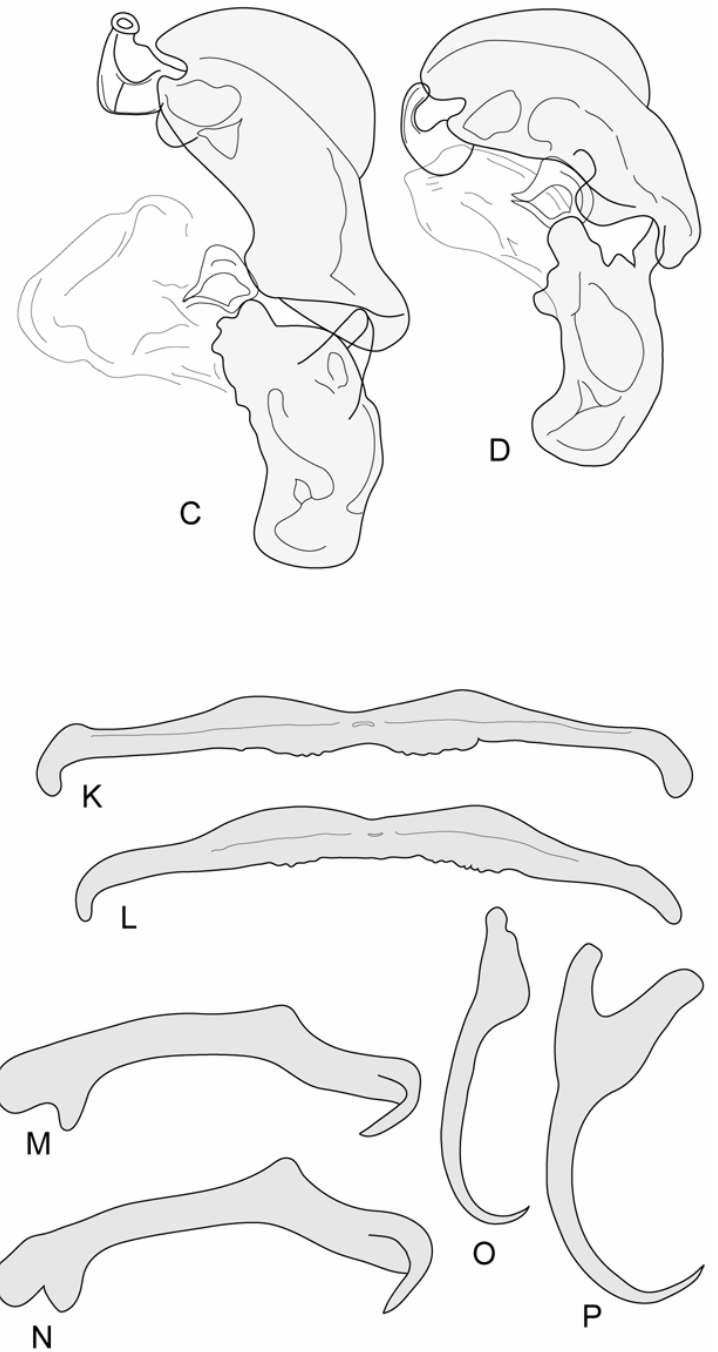

Lethrinus harak

Fig. 1. Calydiscoides difficilis from two hosts, Lethrinus nebulosus (A, B, E-J, left) and L. harak (C, D, K-P, right). For each host is figured a specimen among those having the smallest MCO (A, C), ventral bar (F, L) and dorsal bars $(\mathrm{G}, \mathrm{M})$ and those having the largest MCO (B, D), ventral bar (E, K) and dorsal bars (H, N). E, F, K, L - ventral bars; G, H, M, N - dorsal bars; I, P - ventral hamuli; J, O - dorsal hamuli. All picrate.

M a t e r i a 1 d e p o s i t e d: vouchers from L. nebulosus, $L$. harak, L. obsoletus, L. lentjan, L. ravus in MNHN, JNC334-335; JNC967, JNC1750-1752; JNC1761; JNC1763; JNC1770-1772; JNC1784-1785; JNC1829; vouchers from $L$. nebulosus (2 in each), $\mathrm{BMNH}$ 2006.12.13.4-5, USNPC 99432, MPM 18845-6, HCIP M428/1; vouchers from L. harak, BMNH 2006.12.13.3, USNPC 99433, MPM 18847, HCIP M-428/2; vouchers from L. obsoletus, BMNH 2006.12.13.2, USNPC 99434, MPM 18848, HCIP M-428/3.

P r e v a 1 e n c e : $100 \%$ in L. harak and L. nebulosus, probably $100 \%$ in L. lentjan, L. obsoletus and L. ravus (data incomplete) (Table 1).

I n t e n s i t y : Up to hundreds of specimens per fish. Always the dominant species (see Table 1).
Remarks. The specimens examined are similar to the type specimens (redescribed by Justine 2007a). Oliver (1987) already mentioned that several morphologies of the MCO were visible in the material he examined. We confirm this observation on a much higher number of specimens. $C$. difficilis has a massive MCO in which it is difficult to recognize key structures which could help to differentiate species. Measurements of MCOs are different for specimens from various hosts, but measurements of the $\mathrm{MCO}$ are highly variable within a single host, and we could not recognize specific structures in the MCO which could differentiate different species. Measurements of sclerotized parts of the haptor are generally different for the two main host species ( $L$. nebulosus and L. harak) but the curves overlap (Fig. 2) 

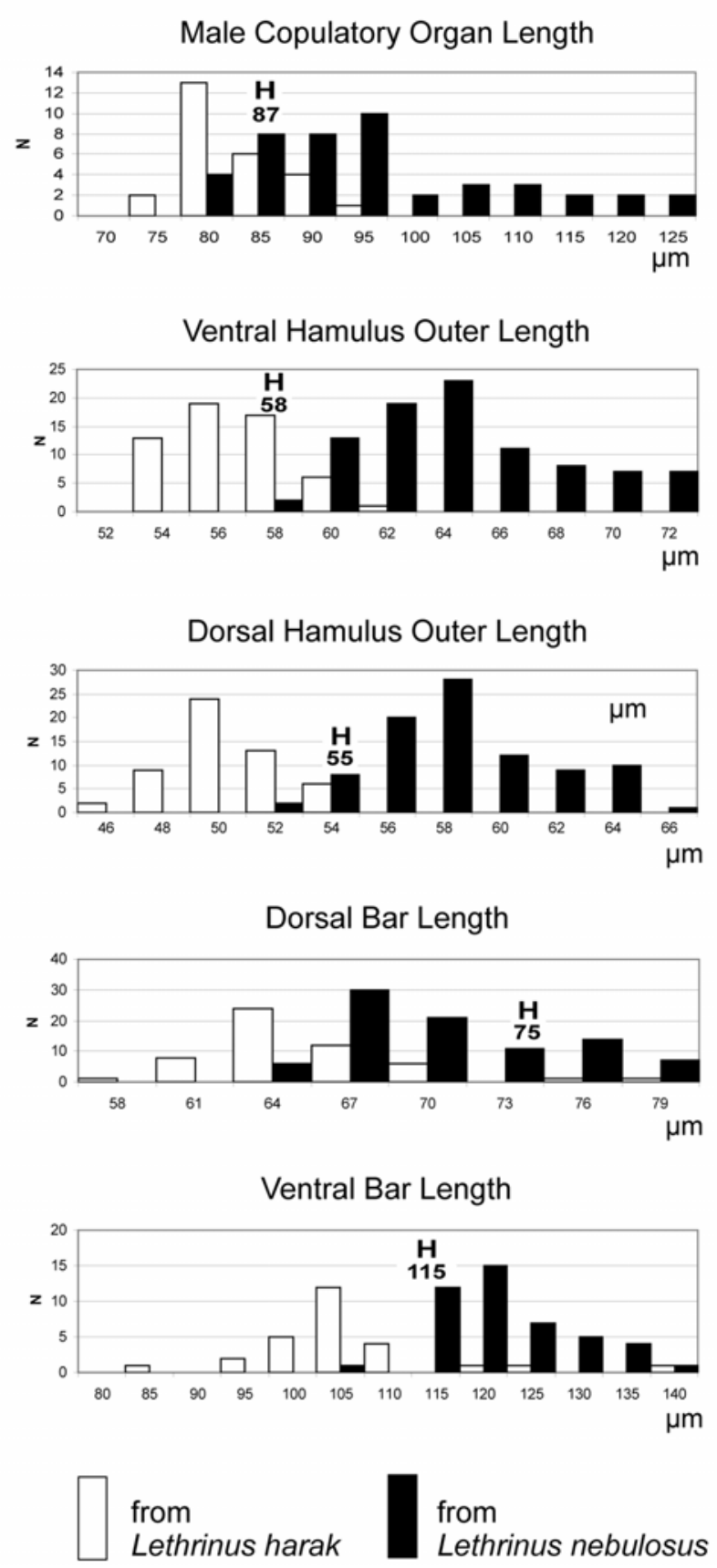

Fig. 2. Calydiscoides difficilis from two hosts, Lethrinus nebulosus and L. harak: histograms of selected measurements. The measurements of the holotype (from an unidentified Lethrinus from Indonesia, Yamaguti 1953) are indicated as $\mathrm{H}$ on each histogram.

and it would be impossible to define taxa on any of these measurements. We performed various statistical tests on measurements (not shown here for brevity) but mainly considered that absence of a key morphological character in the MCO precludes recognition of different taxa. Finally, we conclude that a single species is present: $C$. difficilis has thus a stenoxenous specificity (several hosts with close phylogenetic relationships). However, the high level of morphometric variability suggests that $C$. difficilis may be a species complex, with perhaps one (or sometimes two) cryptic species, each strictly specific, in each host. Absence of $C$. difficilis in several species of Lethrinus, such as L. genivittatus, might be an additional argument for the existence of several cryptic species and against a single generalist species.

Lethrinus harak, L. lentjan, L. ravus and L. obsoletus are new host records; New Caledonia is a new geographical record for $C$. difficilis. The Arabian Gulf (BMNH slides by I. Al-Mathal) is a new geographic record for C. difficilis in L. lentjan. L. nebulosus, $L$. harak and L. lentjan have a wide geographical distribution including Indonesia, the type locality, and also harbour C. duplicostatus: one of these species could be the type host of $C$. difficilis (and also C. duplicostatus) designated as Lethrinus sp. by Yamaguti (1953). C. difficilis was never found in L. miniatus in New Caledonia (Justine 2007a) although it was recorded from this host in Australia (Oliver 1984, Rohde et al. 1994, 1995).

Calydiscoides duplicostatus (Yamaguti, 1953)

Young, 1969

Syn. Lamellodiscus duplicostatus Yamaguti, 1953.

Description of the material from New Caledonia (Fig. 3). Organisation of internal soft organs similar to C. terpsichore (see later). MCO very complex, with two branched processes on superposed planes (Fig. 3 D-H); the MCO shows some variation in morphology according to the specimen and orientation, but measurements are relatively homogeneous (Table 3 ). Sclerotized vagina: a spherical sac, lightly sclerotized, without special differentiation. Haptoral parts: short ventral bar with blunt extremities; dorsal (lateral) bars massive, without external (lateral) hook, medial bifurcated extremity; ventral hamuli elongate, with distinct inner and outer roots; dorsal hamuli elongate, with indistinct inner root (guard). Small lamellodiscs with 9-10 lamellae including 3 closed rings.

T y p e hos t: Lethrinus sp. (Lethrinidae). Species not indicated in the original description, but it was the same individual fish as for $C$. difficilis (see Justine 2007a).

$\mathrm{O} \mathrm{t} \mathrm{h}$ e $\mathrm{r}$ h o s t s : L. nebulosus, L. harak, L. lentjan (this work).

$\mathrm{S}$ i t e : Between secondary gill lamellae.

T y p e 1 o c a 1 i t y : Macassar, Celebes (now Ujungpandang, Sulawesi), Indonesia.

Other loc a lity: New Caledonia (this work).

Material from New Caledonia: 66 specimens; 26 from L. nebulosus; 18 from L. harak; 22 from L. lentjan (see Table 1).

Comparative material examined:MPM 22559, slide SY 6730, holotype and other specimens in type slide (redescribed in Justine 2007a). 


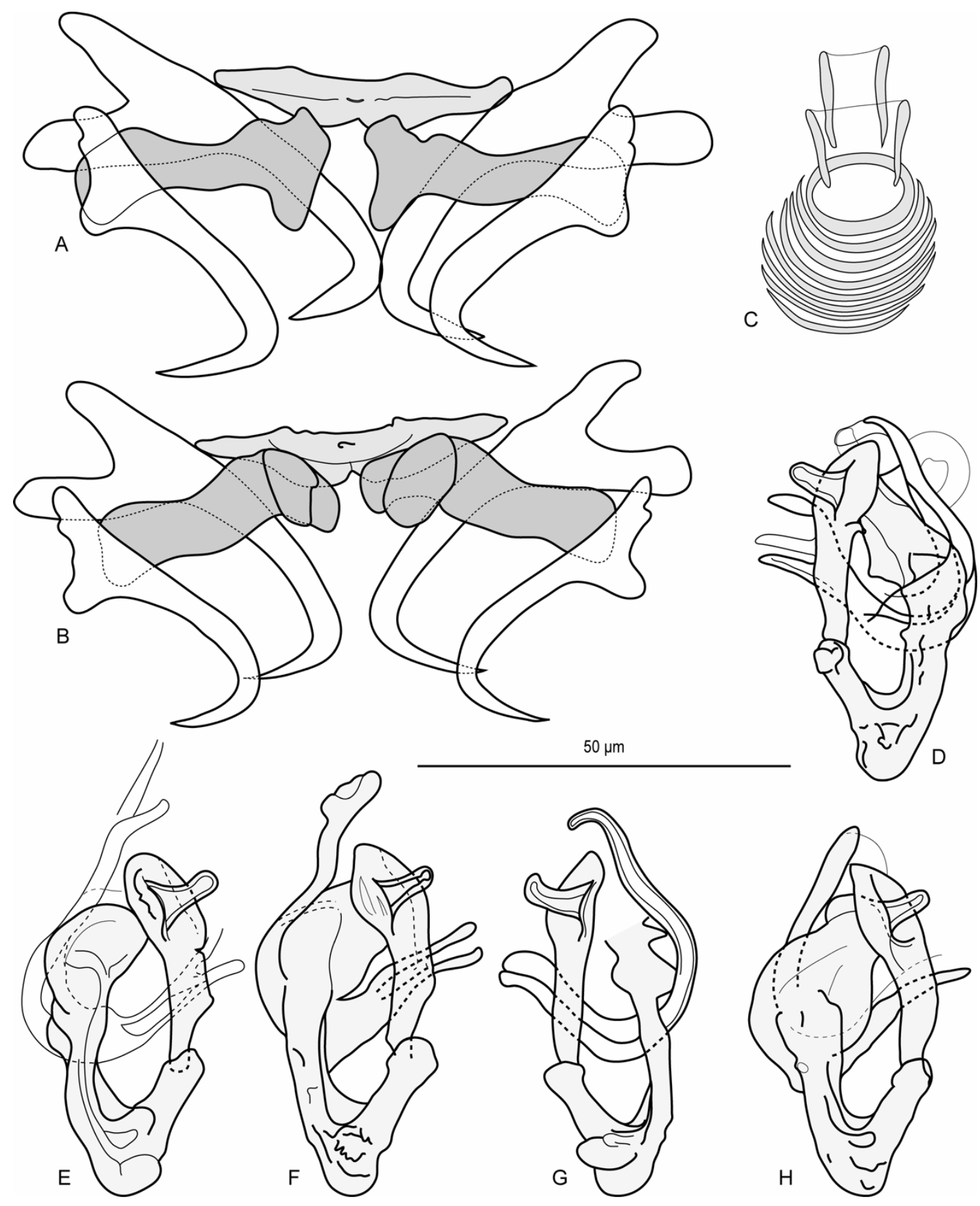

Fig. 3. Calydiscoides duplicostatus from two hosts, Lethrinus nebulosus and L. harak. A, B - haptoral hard parts (A, from $L$. nebulosus; B, from L. harak); C - ventral lamellodisc, from L. nebulosus; D-H - variations of the male copulatory organ according to specimens and orientation (D-G, from L. nebulosus; H, from L. harak); C, D, G, ventral view; A, B, E, F, H, dorsal view.

M a t e rial d e p o s it e d : Vouchers in MNHN, JNC334335; JNC967; JNC1770-1772; JNC1784-1785.

$\mathrm{P}$ r e v a 1 e $\mathrm{n} \mathrm{c}$ e : L. nebulosus $2 / 2,100 \%$; L. lentjan $2 / 2$, $100 \%$; L. harak 4/7, 57\% (Table 1).

I n t e n s i t y : Up to 18 per fish (Table 1); second in number after $C$. difficilis.

Remarks. The specimens examined from the three host species are similar to the type specimens (rede- scribed by Justine, 2007a). The measurements and morphology are similar in specimens from the three hosts examined and there is no reason to doubt that a single species is present in the different hosts. C. duplicostatus has thus a stenoxenous specificity (several hosts with close phylogenetic relationships). This species has the smallest lamellodiscs of all Calydiscoides from lethrinids. 
Table 1. Number of Calydiscoides spp. in Lethrinus spp.

\begin{tabular}{|c|c|c|c|c|c|}
\hline & \multirow[b]{2}{*}{ Fish number } & \multicolumn{4}{|c|}{ Calydiscoides } \\
\hline & & difficilis & duplicostatus & terpsichore sp. n. & undetermined \\
\hline \multirow[t]{8}{*}{ Lethrinus harak } & JNC 1751 & 37 & 0 & 0 & 0 \\
\hline & $\mathrm{JNC} 1750$ & 1 & 0 & 0 & 0 \\
\hline & JNC 1752 & 14 & 0 & 0 & 1 \\
\hline & JNC 1770 & 63 & 5 & 2 & 0 \\
\hline & JNC 1771 & 18 & 1 & 1 & 1 \\
\hline & JNC 1772 & 102 & 10 & 0 & 1 \\
\hline & JNC 1784 & 94 & 2 & 2 & 0 \\
\hline & Total & $329(92.7 \%)$ & $18(5.1 \%)$ & $5(1.4 \%)$ & 3 \\
\hline \multirow[t]{3}{*}{ Lethrinus nebulosus } & JNC 967 & 25 & 8 & 8 & 3 \\
\hline & JNC 1785 & 221 & 18 & 19 & 6 \\
\hline & Total & $246(79.9 \%)$ & $26(8.4 \%)$ & $27(8.8 \%)$ & 9 \\
\hline \multirow[t]{3}{*}{ Lethrinus lentjan } & JNC334 & 11 & 16 & 0 & 1 \\
\hline & JNC335 & 0 & 6 & 0 & 0 \\
\hline & Total & $11(32 \%)$ & $22(65 \%)$ & & \\
\hline \multirow[t]{3}{*}{ Lethrinus ravus } & JNC1761 & 3 & 0 & 0 & 0 \\
\hline & $\mathrm{JNC} 1763$ & 1 & 0 & 0 & 0 \\
\hline & Total & $4(100 \%)$ & & & \\
\hline Lethrinus obsoletus & JNC1829 & $49(100 \%)$ & 0 & 0 & 1 \\
\hline
\end{tabular}

Collections were generally not exhaustive and numbers are given mainly to indicate proportions (indicated as percentages) of various species. A single $L$. variegatus examined had no diplectanid.

Lethrinus nebulosus, L. harak, and L. lentjan are new host records; New Caledonia is a new geographical record. One of these species could be the unnamed type host of C. duplicostatus and C. difficilis (see above).

\section{Calydiscoides terpsichore sp. $\mathrm{n}$.}

Description of specimens from the type host, $L$. nebulosus (Figs. 4, 5). (Measurements of soft parts only from 'carmine' specimens; measurements of hard-parts as indicated). Body elongate, lanceolate, length 600 , $573(500-620, \mathrm{n}=4)$, width 150, $106(75-150, \mathrm{n}=6)$. Tegument smooth. Anterior region with 3 pairs of head organs and 2 pairs of eye-spots; distance between outer margins of anterior eye-spot pair 43, $32(26-43, n=7)$, of posterior eye-spot pair $46,36(31-46, n=7)$. Haptor differentiated from rest of body, width 120, 117 (103$130, \mathrm{n}=7$ ), provided with 2 similar lamellodiscs, 2 pairs of lateral hamuli, 3 bars and 14 marginal hooklets.

Lamellodiscs made up of concentric tubular lamellae. Details of lamellae from centre to periphery (numbering from centre to periphery): 3 complete circles (rings 13 ), 7 incomplete rings (rings 4-10); rings 1-3 thicker than $4-10$, with ring 3 distinctly thicker than all others; rings 4-10 progressively less and less complete, from ring 4 an almost complete circle to ring 10 a short posterior crescent. Ventral and dorsal lamellodiscs similar but ventral slightly larger than dorsal. Ventral lamellodisc round in shape, with $10(\mathrm{n}=7)$ lamellae, length 37,41 $(34-46, \mathrm{n}=5)$, width $40,41(40-45, \mathrm{n}=5)$, internal diameter of first ring $11,12(11-15, \mathrm{n}=6)$; dorsal lamellodisc round in shape, with $10(\mathrm{n}=7)$ lamellae, length 40, $42(39-45, \mathrm{n}=5)$, width $41,42(38-44, \mathrm{n}=$ $4)$, internal diameter of first ring $12,12(10-14, n=4)$. In disturbed lamellodiscs observed laterally, the first ring shows an anteriorly directed triangular point (Fig. $4 \mathrm{E})$; the point is sometimes visible in lamellodiscs ob- served in polar orientation (Fig. 4D). Ventral hamulus elongate, with tubular outer root and thin flattened inner root, outer length in carmine 46, $47(44-53, \mathrm{n}=10)$, in picrate $51 \pm 1.5(49-55, \mathrm{n}=31)$, inner length in carmine $47,48(46-52, \mathrm{n}=10)$, in picrate $52 \pm 1.4(49-54, \mathrm{n}=$ 32). Dorsal hamulus elongate, with indistinct inner root, outer length in carmine 40, $39(36-42, \mathrm{n}=9)$, in picrate $40 \pm 1.2(38-42, \mathrm{n}=32)$, inner length in carmine 26,27 $(23-30, \mathrm{n}=9)$, in picrate $29 \pm 1.6(24-32, \mathrm{n}=32)$. Dorsal (lateral) bars massive, curved anteriorly; curvature c. $150^{\circ}$, at mid length; medial extremity bifurcated; medial ventral and dorsal branches overlapping in moderately flattened ('carmine') specimens, not overlapping and very distinct in highly flattened ('picrate') specimens (Fig. 5); lateral extremity with posteriorly directed blunt protuberance. Length, in carmine $37,36(34-39, \mathrm{n}=$ $10)$, in picrate $41 \pm 2.3(37-47, \mathrm{n}=32)$, width of external part, in carmine $6,7(6-7, \mathrm{n}=10)$, in picrate $8 \pm 1.4$ $(6-11, \mathrm{n}=32)$. Ventral bar thick, with median incision, centre of anterior edge indented, extremities straight, blunt, length in carmine $43,41(39-43, \mathrm{n}=3)$, in picrate $46(41-48, \mathrm{n}=13)$, maximum width in carmine 8,8 (7$8, \mathrm{n}=5)$, in picrate $9(7-11, \mathrm{n}=16)$; groove visible on its ventral side, with crescent-shaped incision in the middle.

Pharynx elongate, length $44,39(27-45, \mathrm{n}=5)$, width $36,32(26-36, \mathrm{n}=5)$. Oesophagus apparently absent, such that intestinal bifurcation immediately follows pharynx. Caeca simple, terminate blindly at level of posterior margin of vitelline field.

Testis subspherical, intercaecal, length 82, 71 (63$82, \mathrm{n}=5)$, width $85,65(56-85, \mathrm{n}=7)$. Vas deferens conspicuous, emerges from antero-sinistral part of testis, enlarges into wide seminal vesicle; seminal vesicle in middle region of body, forms bends, then connects with male copulatory organ (MCO). Prostatic glands con- 


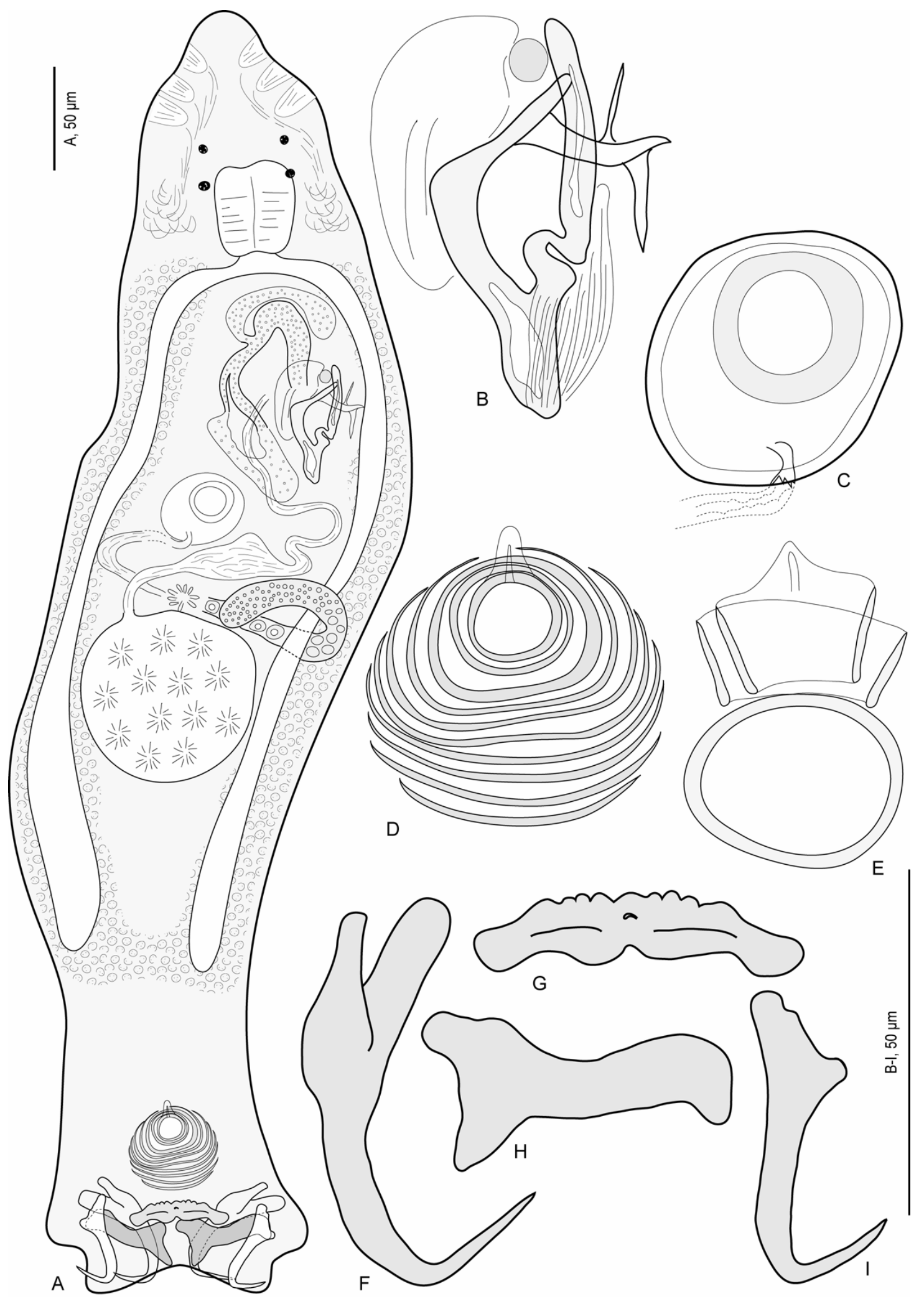

Fig. 4. Calydiscoides terpsichore sp. n. from Lethrinus nebulosus (type host) and L. harak. A - composite view of body, dorsal view; B - male copulatory organ; C - sclerotized vagina; D - lamellodisc, polar view, carmine slide; $\mathbf{E}$ - disturbed lamellodisc showing the shape of the two central rings in 'lateral' view (only three inner rings are figured); $\mathbf{F}$ - ventral hamulus; $\mathbf{G}$ - ventral bar; H - dorsal bar; I - dorsal hamulus. B, C, holotype from L. nebulosus; E-I, paratypes from L. harak. 

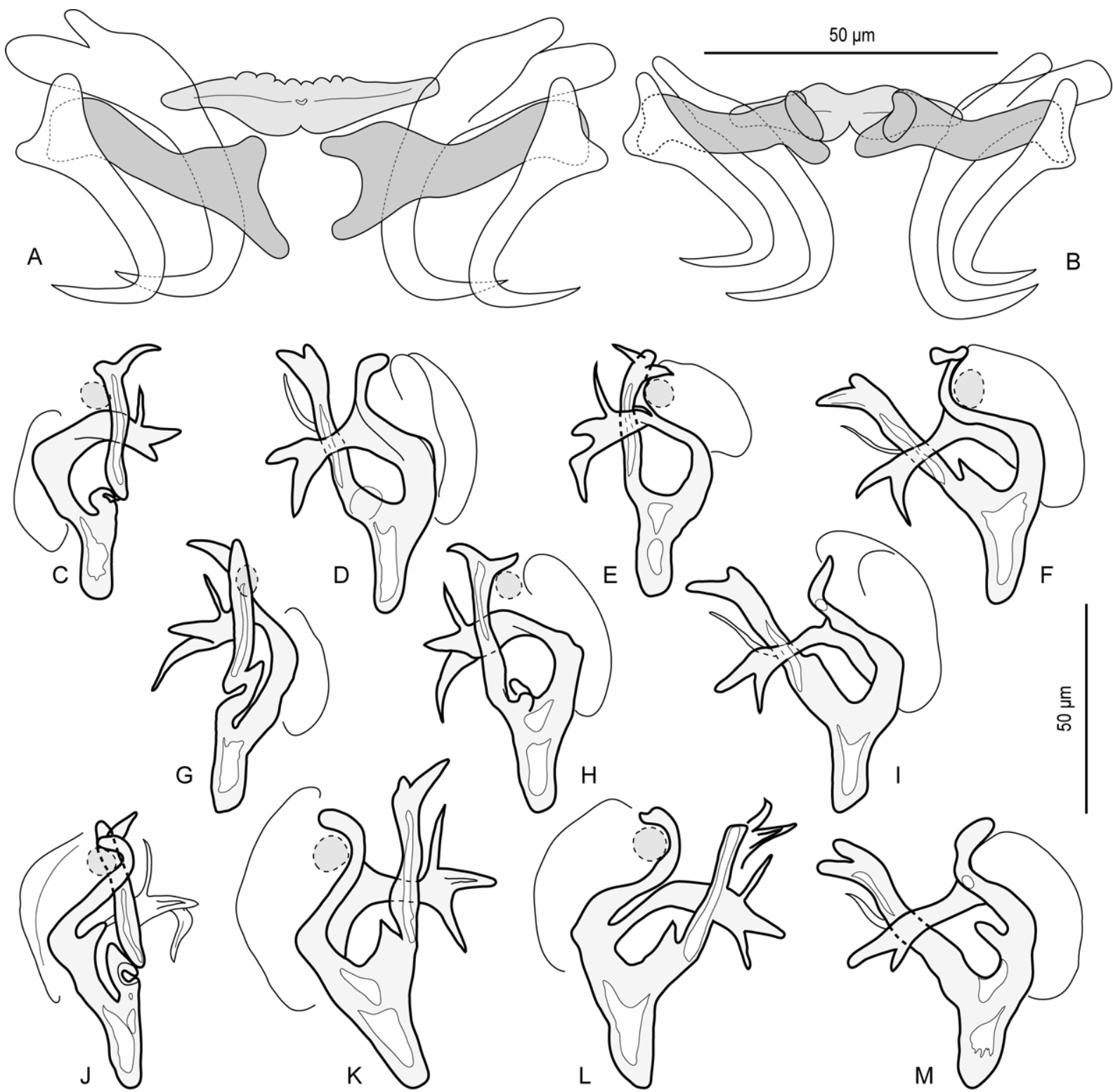

D
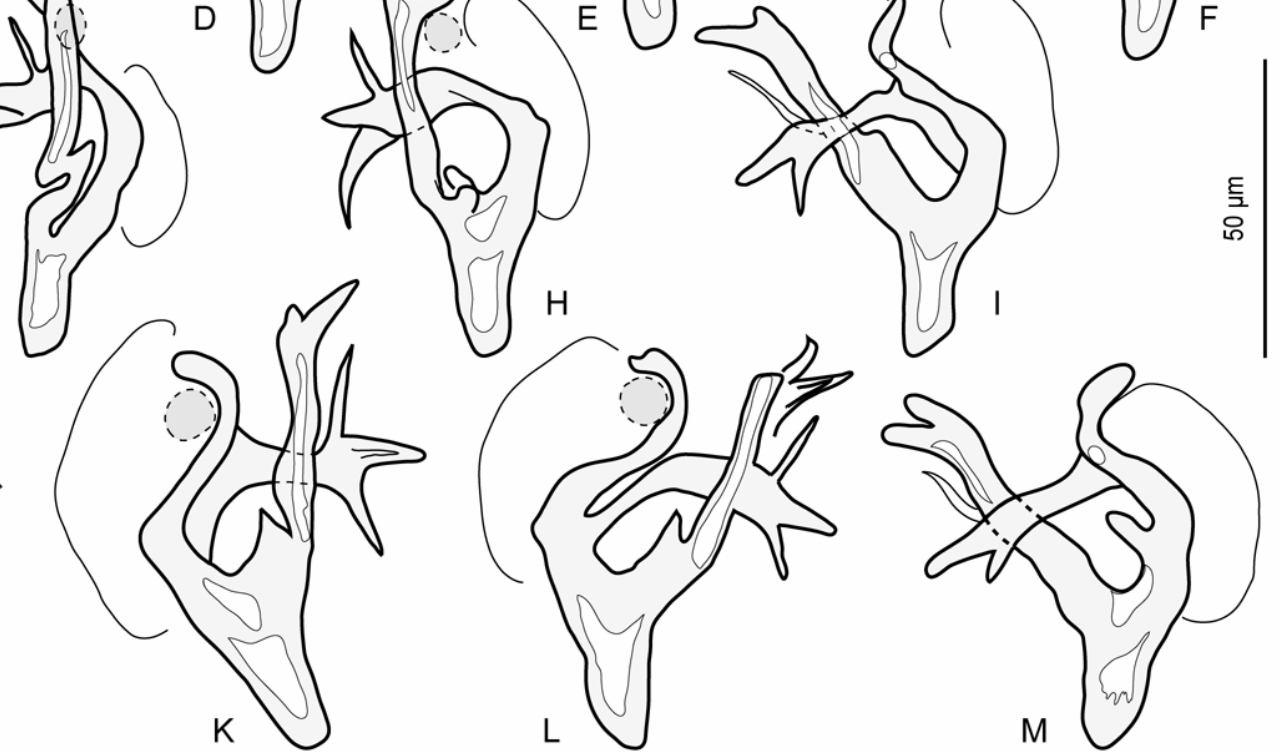

Fig. 5. Calydiscoides terpsichore sp. n. from Lethrinus nebulosus (type host) and L. harak. A - haptoral hard parts, picrate specimen showing forked shape of dorsal bar internal extremities; B - haptoral hard parts, carmine specimen in which the dorsal bar internal extremities do not appear forked; $\mathbf{C}-\mathbf{M}$ - male copulatory organ, slight variations according to specimen and orientation. A, B, C, G, J, K, L, dorsal view; D-I, M, ventral view; C-I, from L. nebulosus; A, B, J-M, from L. harak.

spicuous, anterior and lateral to MCO, connected with conspicuous reservoir; reservoir bends posteriorly to connect with MCO. Sclerotized MCO complex; Yshaped, with base posterior and branches anterior; base and right branch apparently alveolated, left branch solid; right branch straight, with bifurcated extremity; left branch complex, S-shaped in ventral view, with trifurcated branch connected at right angle at mid-length; trifurcated branch crosses ventrally right branch; left branch bordered by sclerotized membrane on its left side; a spherical element, heavily stained by carmine, is often visible in distal curve of S-shaped left branch. Longitudinal muscular fibres are visible along the basal part of the sclerotized MCO. Total length of MCO in carmine 58, $61(58-66, \mathrm{n}=8)$, in picrate $65(59-68, \mathrm{n}=$ 16).

Ovary subequatorial, intercaecal, pre-testicular, encircles dorso-ventrally right caecum. Ovary width 85 , $61(48-85, \mathrm{n}=3)$, length $45,34(25-45, \mathrm{n}=3)$. Oviduct passes medially to form oötype, surrounded by Mehlis' gland; oötype short, opens into uterus. Uterus dextral. Sclerotized vagina: spherical, with small tubular sclerotized element leading to unsclerotized duct. A strong "ring", apparently heavily sclerotized in living specimens or in picrate preparations, coloured in red in carmine specimens, in present in the centre of the sclero- 
Table 2. Measurements of Calydiscoides difficilis in five species of Lethrinus.

\begin{tabular}{|c|c|c|c|c|c|}
\hline Calydiscoides difficilis & L. nebulosus & L. harak & L. lentjan & L. ravus & L. obsoletus \\
\hline \multicolumn{6}{|l|}{ BODY } \\
\hline Body length & c $593(450-745, \mathrm{n}=17)$ & c $432(200-560, n=19)$ & uc $413(340-480, n=3)$ & p $621(530-715, \mathrm{n}=4)$ & $\mathrm{p} 807(610-930, \mathrm{n}=3)$ \\
\hline Body width & c $96(71-130, n=19)$ & c $90(47-135, \mathrm{n}=25)$ & uc $90(70-110, n=3)$ & p $123(90-160, n=4)$ & p $109(85-120, n=4)$ \\
\hline Haptor width & c $170(120-200, n=19)$ & c $138(105-170, \mathrm{n}=25)$ & uc $165(150-180, n=5)$ & p $190(165-215, \mathrm{n}=4)$ & $\mathrm{p} 193(170-210, \mathrm{n}=5)$ \\
\hline \multicolumn{6}{|l|}{ MALE ORGANS } \\
\hline Testis length & c $52(40-80, \mathrm{n}=10)$ & $\mathrm{c} 42(24-64, \mathrm{n}=15)$ & & & \\
\hline Testis width & c $51(37-63, \mathrm{n}=11)$ & $\mathrm{c} 44(22-64, \mathrm{n}=15)$ & & & \\
\hline MCO total length & $\begin{array}{l}\text { c } 82(70-101, n=25) \\
\text { p } 94 \pm 12(77-124, n=42)\end{array}$ & $\begin{array}{l}\text { c } 66(56-92, n=23) \\
\text { p } 81(72-93, n=26)\end{array}$ & uc $97(96-99, \mathrm{n}=5)$ & p $87(77-93, n=4)$ & $\mathrm{p} 87(71-93, \mathrm{n}=5)$ \\
\hline MCO posterior part length & $\begin{array}{l}\text { c } 64(53-74, n=25) \\
\text { p } 72 \pm 8(62-93, n=44)\end{array}$ & $\begin{array}{l}\text { c } 49(42-69, \mathrm{n}=23) \\
\text { p } 60(52-77, \mathrm{n}=28)\end{array}$ & uc $75(66-83, n=5)$ & p $67(58-75, n=4)$ & p $69(61-76, n=5)$ \\
\hline MCO anterior part length & $\begin{array}{l}\text { c } 54(47-67, n=25) \\
\text { p } 65 \pm 11(47-92, n=44)\end{array}$ & $\begin{array}{l}\text { c } 45(41-58, n=23) \\
\text { p } 58(47-67, n=27)\end{array}$ & uc $60(59-62, n=5)$ & p $58(52-63, n=4)$ & p $57(53-59, n=5)$ \\
\hline \multicolumn{6}{|l|}{ FEMALE ORGANS } \\
\hline Ovary width & c $36(25-45, n=4)$ & c $37(19-68, \mathrm{n}=12)$ & & & \\
\hline Ovary length & c $32(18-49, n=4)$ & c $33(22-52, \mathrm{n}=13)$ & & & \\
\hline \multicolumn{6}{|l|}{ HAPTORAL PARTS } \\
\hline Ventral hook outer length & $\begin{array}{l}\text { p } 64 \pm 3.4 \\
(58-72, n=86)\end{array}$ & $\begin{array}{l}\text { c } 51 \pm 3.3(44-57, n=40) \\
\text { p } 56 \pm 2.0(53-62, n=56)\end{array}$ & uc $57(48-62, n=10)$ & p $51(49-54, n=8)$ & $\mathrm{p} 58(53-62, \mathrm{n}=10)$ \\
\hline Ventral hook inner length & $\begin{array}{l}\text { p } 60 \pm 2.7 \\
(53-64, n=86)\end{array}$ & $\begin{array}{l}\text { c } 51 \pm 3.3(43-59, \mathrm{n}=37) \\
\text { p } 54 \pm 1.9(50-58, \mathrm{n}=54)\end{array}$ & uc $58(39-64, n=10)$ & $\mathrm{p} 49(46-53, \mathrm{n}=8)$ & p $55(52-57, \mathrm{n}=10)$ \\
\hline Dorsal hook outer length & $\begin{array}{l}\text { p } 58 \pm 3.0 \\
(52-65, \mathrm{n}=86)\end{array}$ & $\begin{array}{l}\text { c } 46 \pm 4.2(36-57, \mathrm{n}=40) \\
\text { p } 50 \pm 1.9(46-54, \mathrm{n}=54)\end{array}$ & uc $50(31-56, n=10)$ & $\mathrm{p} 45(43-47, \mathrm{n}=8)$ & p $53(47-56, n=10)$ \\
\hline Dorsal hook inner length & $\begin{array}{l}\mathrm{p} 41 \pm 2.4 \\
(34-46, \mathrm{n}=86)\end{array}$ & $\begin{array}{l}\text { c } 32 \pm 3.0(25-39, n=42) \\
\text { p } 34 \pm 1.6(30-37, n=54)\end{array}$ & uc $35(30-38, n=10)$ & p $30(29-31, n=8)$ & p $36(30-40, n=10)$ \\
\hline Dorsal bar length & $\begin{array}{l}\text { p } 69 \pm 4.3 \\
(63-79, n=85)\end{array}$ & $\begin{array}{l}\text { c } 57 \pm 5.2(45-67, n=45) \\
\text { p } 64 \pm 3.6(58-77, n=53)\end{array}$ & uc $69(61-75, \mathrm{n}=10)$ & p $61(56-67, n=8)$ & p $65(58-68, n=10)$ \\
\hline Dorsal bar width & $\begin{array}{l}\text { p } 8 \pm 0.9 \\
(6-11, n=85)\end{array}$ & $\begin{array}{l}\text { c } 5 \pm 0.8(4-7, n=44) \\
\text { p } 7 \pm 0.7(6-9, n=56)\end{array}$ & uc $7(6-8, n=10)$ & $\mathrm{p} 7(6-9, \mathrm{n}=8)$ & $\mathrm{p} 7(5-8, \mathrm{n}=10)$ \\
\hline Ventral bar length & $\begin{array}{l}\text { p } 119 \pm 7.0 \\
(104-138, n=43)\end{array}$ & $\begin{array}{l}\text { c } 90(72-114, n=17) \\
\text { p } 104(82-138, n=27)\end{array}$ & uc $122(113-128, n=5)$ & p $92(87-100, n=4)$ & p $116(96-125, n=5)$ \\
\hline Ventral bar width & $\begin{array}{l}\text { p } 11 \pm 1.2 \\
(8-14, n=43)\end{array}$ & $\begin{array}{l}\text { c } 8(6-14, n=23) \\
\text { p } 10(8-12, n=28)\end{array}$ & uc $8(8-9, n=5)$ & p $10(9-12, n=4)$ & p $10(9-12, n=5)$ \\
\hline Ventral lamellodisc length & c $42(36-48, n=6)$ & c $36(26-44, n=14)$ & & & \\
\hline Ventral lamellodisc width & c $54(44-61, n=6)$ & $\mathrm{c} 42(33-56, \mathrm{n}=18)$ & & & \\
\hline Ventral lamellodisc number & cp $10-11$ & cp 10-11 & uc $10(n=5)$ & $\mathrm{p} 10(\mathrm{n}=3)$ & $\mathrm{p} 10(\mathrm{n}=5)$ \\
\hline $\begin{array}{l}\text { Ventral lamellodisc } \\
\text { closed ring number }\end{array}$ & $\operatorname{cp} 3(n=39)$ & $\operatorname{cp} 3(n=27)$ & uc $3(n=3)$ & $\mathrm{p} 3(\mathrm{n}=3)$ & $\mathrm{p} 3(\mathrm{n}=3)$ \\
\hline $\begin{array}{l}\text { Ventral lamellodisc } \\
\text { internal diameter }\end{array}$ & c $16(12-18, n=6)$ & c $13(11-17, \mathrm{n}=22)$ & & & \\
\hline Dorsal lamellodisc length & c $47(38-56, n=8)$ & c $36(22-43, n=14)$ & & & \\
\hline Dorsal lamellodisc width & c $53(40-60, n=8)$ & c $40 \pm 4.5(34-52)$ & & & \\
\hline Dorsal lamellodisc number & cp $10-11$ & cp 9-12 & uc $10(n=5)$ & $\mathrm{p} 10(\mathrm{n}=3)$ & $\mathrm{p} 10(\mathrm{n}=5)$ \\
\hline $\begin{array}{l}\text { Dorsal lamellodisc } \\
\text { closed ring number }\end{array}$ & $\operatorname{cp} 3(n=40)$ & cp $10-11$ & & $\mathrm{p} 3(\mathrm{n}=3)$ & $\mathrm{p} 3(\mathrm{n}=3)$ \\
\hline $\begin{array}{l}\text { Dorsal lamellodisc } \\
\text { internal diameter }\end{array}$ & $\operatorname{c17}(13-21, \mathrm{n}=10)$ & c $12(6-16, n=22)$ & & & \\
\hline
\end{tabular}

$\mathrm{c}$ - carmine; $\mathrm{p}$ - picrate; $\mathrm{uc}$ - unflattened carmine; $\mathrm{cp}$ - carmine and picrate.

tized vagina in certain specimens, or completely absent. This very visible, but very variable structure, is tentatively interpreted as the content of the vagina, full in recently inseminated specimens. Vitelline fields extend posteriorly from posterior to pharyngeal level in 2 lateral bands, confluent in post-testicular region and terminate anterior to peduncle. Bilateral connections from vitelline fields to oötype inconspicuous. Egg in utero elongate, ovoid.

Specimens from $L$. harak. Specimens from this host are similar to specimens from the type host for mor- phology and measurements. MCO total length, picrate, $69(61-75, \mathrm{n}=3)$, width $30(27-34, \mathrm{n}=3)$. Ventral hamulus, outer length in picrate $51(47-55, \mathrm{n}=6)$, inner length in picrate $51(48-54, \mathrm{n}=6)$. Dorsal hamulus, outer length in picrate $40(38-42, \mathrm{n}=6)$, inner length in picrate $30(28-32, \mathrm{n}=6)$. Dorsal (lateral) bars, length ipicrate $41(35-45, \mathrm{n}=6)$, width of external part in picrate $9(9-11, \mathrm{n}=6)$. Ventral bar, length in picrate 48 $(46-50, \mathrm{n}=3)$, maximum width in picrate $10(8-11, \mathrm{n}=$ $3)$.

T y p e h o s t: Lethrinus nebulosus Forsskål (Lethrinidae). 
Table 3. Measurements of Calydiscoides duplicostatus in three species of Lethrinus.

\begin{tabular}{|c|c|c|c|}
\hline Calydiscoides duplicostatus & L. nebulosus & L. harak & L. lentjan \\
\hline \multicolumn{4}{|l|}{ BODY } \\
\hline Body length & & c $421(355-470, n=4)$ & uc $294(200-340, n=5)$ \\
\hline Body width & & c $75(65-85, \mathrm{n}=4)$ & uc $66(60-70, n=5)$ \\
\hline Haptor width & & c $69(65-70, n=4)$ & uc $73(70-80, n=4)$ \\
\hline \multicolumn{4}{|l|}{ MALE ORGANS } \\
\hline MCO total length & p $48(44-52, n=9)$ & c $37-45(n=2)$ & uc $37(33-41, n=5)$ \\
\hline \multirow{3}{*}{ MCO branches maximum width } & & p $47(45-48, n=7)$ & \\
\hline & p $20(17-23, \mathrm{n}=9)$ & c $19-21(\mathrm{n}=2)$ & uc $12(7-15, \mathrm{n}=5)$ \\
\hline & & p $22(17-24, n=7)$ & \\
\hline \multicolumn{4}{|l|}{ HAPTORAL PARTS } \\
\hline Ventral hook outer length & p $49(46-52, n=18)$ & p $49(45-54, \mathrm{n}=14)$ & uc $38(34-42, \mathrm{n}=10)$ \\
\hline Ventral hook Inner length & p $47(45-52, n=18)$ & p $47(44-50, n=14)$ & uc $40(29-44, \mathrm{n}=10)$ \\
\hline Dorsal hook outer length & p $38(35-40, n=18)$ & p $38(34-43, n=14)$ & uc $33(32-36, \mathrm{n}=10)$ \\
\hline Dorsal hook Inner length & p $26(24-28, \mathrm{n}=18)$ & p $27(24-31, n=14)$ & uc $22(21-24, \mathrm{n}=10)$ \\
\hline Dorsal bar length & p $31(29-34, n=18)$ & p $32(27-35, \mathrm{n}=14)$ & uc $25(23-25, \mathrm{n}=7)$ \\
\hline Dorsal bar width & p $8(6-13, n=18)$ & p $9(7-12, n=14)$ & uc $6(6-7, n=7)$ \\
\hline Ventral bar length & p $38(34-41, n=9)$ & p $40(36-43, n=7)$ & \\
\hline Ventral bar width & p $6(5-8, n=8)$ & p $7(5-9, n=7)$ & uc $6(5-6, n=4)$ \\
\hline Ventral lamellodisc number & $\operatorname{cp} 10(\mathrm{n}=11)$ & cp $9-11(n=8)$ & c $10(\mathrm{n}=5)$ \\
\hline Ventral lamellodisc closed ring number & & $\operatorname{cp} 3(n=3)$ & uc $3(n=3)$ \\
\hline Ventral lamellodisc internal diameter & c $8(6-10, \mathrm{n}=6)$ & c $7(6-8, n=5)$ & \\
\hline Dorsal lamellodisc number & $\operatorname{cp} 10(\mathrm{n}=12)$ & $\mathrm{cp}(9-10, \mathrm{n}=8)$ & uc $10(\mathrm{n}=5)$ \\
\hline Dorsal lamellodisc closed ring number & & $\operatorname{cp} 3(n=3)$ & \\
\hline Dorsal lamellodisc internal diameter & c $8(6-12, n=7)$ & c $6(5-7, n=5)$ & \\
\hline
\end{tabular}

$\mathrm{c}$ - carmine; $\mathrm{p}$ - picrate; $\mathrm{uc}$ - unflattened carmine; $\mathrm{cp}$ - carmine and picrate.

Table 4. Species of Lethrinus present off New Caledonia and their Calydiscoides species. From Justine (2007a), and this paper.

\begin{tabular}{|c|c|c|}
\hline Lethrinus spp. & Examined & Calydiscoides spp. \\
\hline L. atkinsoni Seale & + & C. rohdei \\
\hline \multicolumn{3}{|l|}{ L. erythracanthus Valenciennes } \\
\hline L. genivittatus Valenciennes & + & $0^{*}$ \\
\hline $\begin{array}{l}\text { L. harak Forsskål } \\
\text { L. laticaudis Alleyne et Macleay }\end{array}$ & + & C. difficilis, C. duplicostatus, C. terpsichore sp. n. \\
\hline L. lentjan Lacépède & + & C. difficilis, C. duplicostatus \\
\hline L. miniatus Schneider & + & C. australis, $C$. gussevi \\
\hline L. nebulosus Forsskål & + & C. difficilis, C. duplicostatus, C. terpsichore sp. $\mathrm{n}$. \\
\hline L. obsoletus Forsskål & + & C. difficilis \\
\hline \multicolumn{3}{|l|}{ L. olivaceus Valenciennes } \\
\hline L. ravus Carpenter et Randall & + & C. difficilis \\
\hline L. rubrioperculatus Sato & + & C. euzeti \\
\hline \multicolumn{3}{|l|}{ L. semicinctus Valenciennes } \\
\hline L. variegatus Valenciennes & + & 0 ** \\
\hline L. xanthochilus Klunzinger & + & C. euzeti \\
\hline
\end{tabular}

*based on numerous $(>30)$ observations; **based on a single fish examined.

Table 5. Host specificity of Calydiscoides spp. from Lethrinus spp. in New Caledonia. From Justine (2007a), and this paper. Specificity is strict (1 host species) or stenoxenous (2-5 host species).

\begin{tabular}{lcl}
\hline Species & Number of hosts & Hosts \\
\hline C. australis & 1 & L. miniatus \\
C. rohdei & 1 & L. atkinsoni \\
C. gussevi & 1 & L. miniatus \\
C. euzeti & 2 & L. rubrioperculatus, L. xanthochilus \\
C. terpsichore & 2 & L. nebulosus, L. harak \\
C. duplicostatus & 3 & L. nebulosus, L. harak, L. lentjan \\
C. difficilis* & 5 & L. nebulosus, L. harak, L. lentjan, L. ravus, L. obsoletus \\
\hline
\end{tabular}

*additional hosts in Australia are L. laticaudis, L. reticulatus and L. miniatus (Young 1969, 1970, Oliver 1984, Rohde et al. 1994, 1995), producing a total number of 8 host species for $C$. difficilis for both locations. 
O t h e r h o s t: Lethrinus harak Forsskål.

$\mathrm{S}$ i t e : Between secondary gill lamellae.

T y p e 1 o c a lity: Lagoon off Nouméa, New Caledonia.

T y p e s p e c i m e n s : Holotype, slide JNC967A17; 30 paratypes.

Material examined: 32 specimens.

M a t e r i a 1 d e p o s i t e d : Holotype and 21 paratypes from $L$. nebulosus (3 'carmine', 18 'picrate' in 14 slides), MNHN JNC967, JNC1985; 5 paratypes from L. harak (2 'carmine', 3 'picrate' in 2 slides, MNHN JNC1770, JNC1771, JNC1784; paratypes from L. nebulosus, 'carmine': BMNH 2006.12.13.7; USNPC 99431; MPM 18844; HCIP M-427.

P r e v a 1 e n c e : L. nebulosus $2 / 2,100 \%$; L. harak $3 / 7,42 \%$ (Table 1).

I n t e n s i t y : Up to 19 per fish. Always less abundant than C. difficilis; apparently as abundant as $C$. duplicostatus in L. nebulosus, but the less abundant species in L. harak (Table 1).

E t y m o 1 o g y : Specific name is from Terpsichore, the Muse of dancing, in reference to the morphology of the MCO which evokes the leg of a dancer to the first author.

Differential diagnosis. Justine (2007a) proposed to differentiate two groups within the Calydiscoides from lethrinids, i.e. the 'difficilis group' (including $C$. difficilis and $C$. rohdei), characterized by heavily sclerotized $\mathrm{MCO}$, and the 'australis group' (including $C$. australis, C. duplicostatus, C. gussevi and C. euzeti) in which the MCO is branched. C. terpsichore clearly belongs to the australis group. It can be differentiated from other members of the group by the morphology of its MCO, particularly the lateral trifurcated branch. Haptoral hard parts are similar in size in all five members of the australis group (including $C$. terpsichore); $C$. terpsichore can be distinguished from $C$. euzeti, but not from the three other species, by absence of hooks on dorsal bars. Lamellodiscs are also similar in all members in the groups; $C$. terpsichore can be distinguished from $C$. duplicostatus, but not from the three other species, by larger squamodiscs (37 vs 25).

\section{DISCUSSION}

\section{Comments on the MCO}

Homologies between the different parts of the MCO and functional morphology can be hypothesized from similar structures. The left branch is bordered, or ended, by a membranous element in Calydiscoides terpsichore, as it is in $C$. australis and $C$. euzeti. The right branch has a small bend at its base in $C$. terpsichore and $C$. euzeti: this could be a zone of flexion assuring mobility of this part.

Comments on host specificity of Calydiscoides spp. and numerical evaluation of parasite biodiversity

A host-parasite list is given in Table 4, and host specificity of the 7 Calydiscoides spp. collected from New Caledonian fish is indicated in Table 5. Specificity is not strict for several species. This contrasts with an- other diplectanid genus, Pseudorhabdosynochus, in which specificity in groupers is very strict (Justine 2007b). However, when a Calydiscoides species (identified by MCO morphology) is found in several hosts, morphometrics are different in each host (Justine 2007a, for $C$. euzeti; this paper, for $C$. difficilis); this suggests that species complexes might be involved.

In term of coincidences of host and parasite phylogeny, it is worth mentioning that Lethrinus harak and $L$. nebulosus are two members of a terminal clade, containing 4 members, in the phylogeny of Lethrinidae of Lo Galbo et al. (2002; their fig. 2); these two species are the only ones to harbour $C$. terpsichore, which is apparently limited to this terminal clade. L. lentjan, which is closely related to this clade, shares $C$. duplicostatus with the two former host species. $C$. difficilis has a wide host spectrum of five species in New Caledonia, plus $L$. laticaudis and L. reticulatus in Australia (Young 1969, 1970) and, if specimens mentioned by Oliver (1984) and Rohde et al. (1994) belong to the same species, also L. miniatus in Australia. L. miniatus is the basal species of the Lethrinus clade in Lo Galbo et al. (2002): $C$. difficilis is thus a species with a very wide host spectrum, occurring in all three major clades recognized within Lethrinus by Lo Galbo et al. (2002). However, measurement differences suggest that differentiation of several parasite species (perhaps a ' $C$. difficilis species complex') is occurring, or has occurred, but morphological differences are too subtle to be ascertained to the observer, without genetic methods.

In term of numerical evaluation of parasite biodiversity, the case of stenoxenous species (which have several closely related hosts) such as Calydiscoides spp. produces a 'parasitic biodiversity ratio' (number of parasite species: number of host species) lower than for oioxenous species (which have a single host). In New Caledonia, Justine (2007b: his table 5) recorded that 7 species of groupers (Epinephelinae) had a total of 25 species of diplectanids, which were all strictly specific; this produces a parasitic biodiversity ratio of 3.57 (25:7). For Lethrinus and Calydiscoides, the counts for New Caledonia are of 7 species of diplectanids for 11 species of hosts (Table 4), thus a parasitic biodiversity ratio of 0.63 (7:11), inferior to 1 . However, several species of Haliotrema are also present in almost all Lethrinus species (Justine 2007a; and unpublished results) and might show a higher degree of host specificity.

\section{Other parasites from $L$. harak and $L$. nebulosus}

In addition to the diplectanid species described above, L. harak has 3 species of the ancyrocephalid Haliotrema, all probably new, and L. nebulosus has one species, which is similar to one of the species from $L$. harak. Both fish have copepods on gills, identified by G. Boxshall (Natural History Museum, London) as Hatschekia sp. (Hatschekiidae). Both fish have capsalids, Encotyllabe sp. (probably the same species) on 
pharyngeal teeth. L. harak has also a gnathiid isopod larvae, a filiform didymozoid digenean within the gill arches, and a leech (Hirudinea) was found once. Immature microcotylid polyopisthocotyleans were collected in L. nebulosus. Finally, L. harak has 10 gill and mouth parasites, including 7 monogeneans (3 diplectanids, 3 ancyrocephalids, 1 capsalid), 1 leech, 1 isopod and 1 copepod, and L. nebulosus has 7 gill and mouth parasites, including 6 monogeneans (3 diplectanids, 1 ancyrocephalid, 1 capsalid, 1 microcotylid) and 1 copepod. $L$. nebulosus and $L$. harak thus apparently share 3 diplectanids, 1 ancyrocephalid and 1 capsalid, thus confirming close relationships between the two species.
Both species also have opecoelid digeneans, still unidentified, in the digestive tract; opecoelids have already been reported from various Lethrinus spp. off New Caledonia (Bray and Justine 2007).

Acknowledgements. Sam Tereua, Miguel Clarque and Napoléon Colombani, captains of the $\mathrm{R} / \mathrm{V}$ 'Coris' provided safe navigation. Gérard Mou Tham (IRD) spear fished certain specimens. Angelo di Matteo (IRD) provided technical help. Geoffrey Boxshall (NHM, London, England) agreed to study the copepods. Jimmy Cassone (MNHN, Paris), Eric P. Hoberg and Pat Pilitt (USNPC, Beltsville), David Gibson and Eileen Harris (BMNH, London) and Takashi Iwaki (MPM, Tokyo) kindly arranged the loan of Museum specimens.

\section{REFERENCES}

BRAY R., Justine J.-L. 2007: Pseudopycnadena tendu sp. nov. (Digenea, Opecoelidae) in the yellow-spotted triggerfish Pseudobalistes fuscus (Perciformes, Balistidae) and additional opecoelids parasitizing fishes from the waters off New Caledonia. Acta Parasitol. 52: 13-17.

FriCKE R., KULBICKI M. 2006: Checklist of the shore fishes of New Caledonia. In: C.E Payri and B. Richer de Forges (Eds.), Compendium of Marine Species from New Caledonia. Documents Scientifiques et Techniques II7. Institut de Recherche pour le Développement, Nouméa, New Caledonia, pp. 313-357.

Froese R., PAUly D. (Eds.) 2006: FishBase. World Wide Web electronic publication. www.fishbase.org.

Hinsinger D.D., Justine J.-L. 2006: The 'Pseudorhabdosynochus cupatus group' (Monogenea: Diplectanidae) on Epinephelus fasciatus, E. howlandi, E. rivulatus and E. merra (Perciformes: Serranidae) off New Caledonia, with descriptions of Pseudorhabdosynochus cyathus $\mathrm{n}$. sp. and P. calathus n. sp. Syst. Parasitol. 64: 69-90.

Justine J.-L. 2005: Species of Pseudorhabdosynochus Yamaguti, 1958 (Monogenea: Diplectanidae) from Epinephelus fasciatus and E. merra (Perciformes: Serranidae) off New Caledonia and other parts of the Indo-Pacific Ocean, with a comparison of measurements of specimens prepared with different methods, and a description of $P$. caledonicus n. sp. Syst. Parasitol. 62: $1-37$.

JUSTINE J.-L. 2007b: Parasite biodiversity in a coral reef fish: twelve species of monogeneans on the gills of the grouper Epinephelus maculatus (Perciformes: Serranidae) off New Caledonia, with a description of eight new species of Pseudorhabdosynochus (Monogenea: Diplectanidae). Syst. Parasitol. 66: $81-129$

Justine J.-L. 2007a: Species of Calydiscoides Young, 1969 (Monogenea: Diplectanidae) from lethrinid fishes, with the redescription of all the type-specimens and the description of C. euzeti n. sp. from Lethrinus rubrioperculatus and L. xanthochilus off New Caledonia. Syst. Parasitol. 67:187-209.
LABOUTE P., GRANDPERRIN R. 2000: Poissons de NouvelleCalédonie. Éditions Catherine Ledru, Nouméa, New Caledonia, 520 pp.

LIM L.H.S. 2003: Species of Calydiscoides Young, 1969 (Monogenea: Diplectanidae Bychowsky, 1957: Lamellodiscinae Oliver, 1969) from nemipterid fishes off Peninsular Malaysia. Syst. Parasitol. 55: 115-126.

Lo GAlbo A., CARPENTER K.E., REED D.L. 2002: Evolution of trophic types in emperor fishes (Lethrinus, Lethrinidae, Percoidei) based on cytochrome $b$ gene sequence variation. J. Mol. Evol. 54: 754-762.

OLIVER G. 1984: Quelques espèces du genre Calydiscoides Young (Monogenea, Monopisthocotylea, Diplectanidae), parasites de Perciformes du Récif de la Grande Barrière (Australie). Zool. Scr. 13: 189-193.

OLIVER G. 1987: Les Diplectanidae Bychowsky, 1957 (Monogenea, Monopisthocotylea, Dactylogyridea). Systématique. Biologie. Ontogénie. Écologie. Essai de phylogenèse. Thèse d'État, Académie de Montpellier, Université des Sciences et Techniques du Languedoc, 433 pp.

ROHDE K., HAYWARD C., HEAP M. 1995: Aspects of the ecology of metazoan ectoparasites of marine fishes. Int. J. Parasitol. 25: 945-970.

RoHDE K., HAYWARD C., HeAP M., GosPer D. 1994: A tropical assemblage of ectoparasites: gill and head parasites of Lethrinus miniatus (Teleostei, Lethrinidae). Int. J. Parasitol. 24: 1031-1053.

THONEY D.A. 1989: Morphology of Calydiscoides nemipteris, sp. nov. (Monogenea), with a redescription and revision of the genus. Aust. J. Zool. 37: 37-43.

YAMAGUTI S. 1953: Parasitic worms mainly from Celebes. Part. 2 Monogenetic trematodes of fishes. Acta Med. Okayama 8: 203-256 + IX P1.

YounG P.C. 1969: Some monogenoideans of the family Diplectanidae Bychowsky, 1957 from Australian teleost fish. J. Helminthol. 43: 223-254.

YounG P.C. 1970: The species of Monogenoidea recorded from Australian fishes and notes on their zoogeography. An. Inst. Biol. Univ. Nac. Auton. México 41, Sér. Zool. (I): 163-176.

Accepted 2 March 2007 